\title{
Learning to Gain Wisdom: Experience of MNCs Accounting Managers
}

\author{
Li-Chung Chang ${ }^{1, a}$, Ru-Pin Dong ${ }^{2, b}$, Ran Lee ${ }^{3, c}$, Xiang Li $^{4, d}$ \\ ${ }^{1}$ \#1038 Guangcongroad Zhong Latan Baiyun District Guangzhou (Guangzhou Zhong Latan \\ University Park), China.\#1 Xueyuan Road, Zhongshan City, Guangdong province, China. \\ 2,3,4\#1038 Guangcongroad Zhong Latan Baiyun District Guangzhou (Guangzhou Zhong Latan \\ University Park), China.

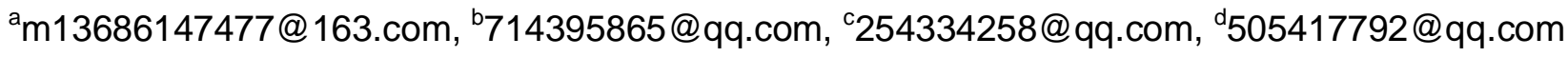

Keywords: learning, wisdom, MNC, Accounting manager

Abstract:Managers learning approach emphasizing the most efficient way to procure knowledge and wealth has reached its limits. Learning and wisdom creation pattern from a multicultural perspective has been called among scholars. In order to explore how successful MNC(Multinational Corporation)s accounting managers' learn to gain wisdom in such a setting, 6 MNC's accounting managers were selected and interviewed. This study found that there are 3 patterns of learning and of gaining wisdom suitable for managers in western, eastern or mixed cultural backgrounds.

\section{Introduction}

Motivation. Knowledge management emphasizing the most effective way to create, use and share tacit and explicit knowledge (Nonaka, 1991;Nonaka \& Takeuchi, 1995) has become one of the most important theory in the $20^{\text {th }}$ century, yet such emphasis to produce knowledge and wealth (Blasco, 2009; Nonaka, Chia, Holt \& Peltokorpi, 2012) has found its limits, since the financial crisis erupted. Purposes: theoretical gap Learning approaches to gain wisdom have been widely discussed from eastern and western view, yet learning patterns to gain wisdom insufficient attention has been paid. Obliviously, the world is in need of learning patterns to gain wisdom from a complete (multicultural) perspective and use of wisdom to cope with this complex world (Rowley, 2006 ). This paper will reviews literature by comparing approaches from an eastern and western based multicultural perspective.

\section{Literature Review}

\section{Approaches of learning and wisdom creation}

Consequential vs Non-consequential. The first main difference is consequential or non-consequential. In the west, peoples' portrayal of human action is overwhelmingly expressed as in a calculative and consequentialist tradition. Action is seen as choice, and choice is seen as driven by anticipations, incentives, and desires (March, 2003). By contrast, the eastern view places more emphasis on satisfaction in finding truth than in the consequence of material gains (Tang,1980).

Analytical vs Holistic. The second main difference is analytical or holistic. In the west, people tend to be analytical, a logic view which cannot accommodate the simultaneous validity of contradictory circumstances. Western people tend to think and learn in logical, linear patterns and they assume they can employ and shape nature to their own ends (Scarborough, 1998; Tang, 1980).

By contrast, eastern thinking and learning has traditionally embraced a holistic view of the world (Yang, Zheng \& Li, 2006). 
Conceptual vs Nonconceptual. The third main difference is the conceptual or non-conceptual (Droit, 2004). Weick and Sutcliffe (2006) argues that the information-processing emphasis in western approaches concentrates on concepts and on making distinctions while the eastern approach emphasizes non-conceptual awareness and reduced distraction.

Western thinking tends to place emphasis on concepts, knowledge, theories, ideas or skills based learning (Baark, 2005; Chia, 2005; Chia \& Holt, 2008; Senge, 2006). This learning approach is the straightforward adoption of knowledge, providing a skill that enables individuals to carry out predefined operating routines. In the terminology of March (1991), this approach of learning may be characterized as purely based on exploitation of knowledge.In contrast, eastern thinking tends to emphasize non-conceptual learning approach which is practice based learning. Non-conceptual learning gives the sense to management of an immersed perception, coping, and sense-making process: a set of skilled integrative social practices which may draw from representational forms of knowledge. As a practice, it is more an art than a science (Chia \& Holt, 2008).

Internal vs External. The fourth main difference is the internal or external. In the west, to be where you are with all your mind means to pay more attention to external events and to the content of the mind, these contents include things such as past associations, concepts, reifications, and semblances of sensed objects (deCharms, 1998). The eastern way of thinking has more emphasis on action, the action will guide feeling and thinking (Tang, 1980). In the East, to be where you are with all your mind means to pay more attention to internal processes of mind rather than to the contents of the mind.

Mindful vs Less Mindful. Levinthal and Rerup(2006) found that the eastern and western difference is that eastern wisdom is produced through mindfulness and western knowledge is produced from less mindfulness.Mindfulness is a flexible state of mind in which we are actively engaged in the present, noticing new things and sensitive to context (Langer, 2000) and it is also conceived as involving attentiveness and the ability to respond flexibly to contextual cues (Argote, 2006).

Impacts. The positive impact of western learning is its efficiency in reaching a practical wisdom.

Eastern learning and wisdom place more emphasis on cultivation of virtue than on efficiency.

\section{Methods}

\section{Types (Strategies) of Design.}

This research adopts multi-cases study allowing for replication logic, that is, each case serving to confirm or deny the inference drawn from the others (Yin, 2008). This study also employed embedded analysis units consistent to focus on each firm.

Data Sources. Six cases were selected via the principle of purposive sampling of logic replication. They were interviewed several times individually via 6 semi-structured sub-questions (Cooper \& Schindler, 2010) framed by constructive indicators of the frameworks. Through the interview with repeated and deep inquiry, data can be tested via triangulation.

Data Analysis. The purpose of this research was to explore the learning process to gain wisdom. Therefore, it was suitable to adopt 'time series analyses,' 'pattern matching' and 'cross-case synthesis' (Yin, 2008). In the process of analysis, we first performed within-case analysis to find the main traits of the process from single cases, then we compared all cases to find replication of the learning process. The data collection and analysis were usually synchronized. Data collection stopped when theoretical saturation was achieved.

\section{Result}

First, MNC accounting managers describes "why do they learn and gain wisdom?". The case 01 accounting manager showed that learning was for problem solving not for pleasure. The case 02 accounting manager had a similar tendency to case 01 and indicated that learning is the process of problem solving passively.

The case 03 accounting manager indicated that learning has both a satisfaction and problem solving 
purpose. The case 04 accounting manager has a similar tendency as case 03 . The case 05 accounting manager indicated that learning is a happy thing and makes him feel like he is in recharging. The case 06 accounting manager had a similar option as the case 05 .

Second, MNC accounting managers describe "how are accounting managers driven to learn and gain wisdom?". The case 01 accounting manager showed that the source of problem solving learning is professional knowledge. The case 02 accounting manager has a similar tendency as the case 01 manager and indicated that he needs ideas (professional knowledge) to solve problems. The case 03 accounting manager indicated that his learning is from both experience and professional knowledge. The case 04 accounting manager has expressed a similar tendency as case 03 . The case 05 accounting manager indicated that life experience is the best teacher. The case 06 accounting manager has expressed a similar tendency as case 05.

Third, MNC accounting managers describe "how do accounting managers think from various viewpoints and gain wisdom". The case 01 accounting manager indicated that she seldom think differently. The case 02 accounting manager has a similar view (tendency) as case 01 .

The case 03 accounting manager indicated that he will argue with his boss in order to widen thinking and open up new points of view. The case 04 accounting manager has a similar view(tendency) as case 3 . The case 05 accounting manager indicated that he will use different viewpoints for different employees. The case 06 accounting manager has a similar option (tendency) as case 5.

Fourth, MNC accounting managers describe "what is the source of learning and wisdom creation for accounting manager (searching from knowledge or action) ?". The case 01 accounting manager indicated that she will discuss and clarify knowledge with professional persons external to her firm before taking action. The case 02 accounting manager expressed a similar tendency as case 01 . The case 03 accounting manager indicated that his learning combines thinking and action for the duration. He also indicated that he will ask for instructions (knowledge) from the boss before taking action. The case 04 accounting manager has expressed a similar tendency as case 3 . The case 05 accounting manager indicated that if you are without (inter)action then you are without knowledge. The case 06 accounting manager has similar views (tendency) as case 5 and indicated that you need to interact and then understand how to do things.

Fifth, MNC accounting managers describes "how do accounting manager use their mind (are they capable of sensing and responding to change of environment) and gain wisdom?". The case 01 accounting manager did not think mindfulness was important. The case 02 accounting manager had a similar tendency as case 01 . The cases 03 accounting manager indicated that using (realizing) and not using mindfulness are equally important. The case 05 accounting manager emphasize the importance of mindful and realization. The case 06 accounting manager had similar tendencies as case 05.

Finally, accounting managers describe the impacts. The case 01 accounting manager indicated that she will apply what she learned to improve performance.The case 02 accounting manager has similar tendency as case 01 . The case 03 accounting manager indicated that he insists to do things for both performance and wisdom accumulation. The case 04 accounting manager has a similar view (tendency) as case 03 . The case 05 accounting manager indicated that he will share what he learned to accumulate wisdom with satisfaction.

\section{Findings}

This study finds three patterns of learning and gain wisdom via induction of research results from six cases. The western learning approach starts from the motivation of problem-solving, and then a learner will search for related knowledge via single perspective and consult to external experts to solve the problem and focus on the result. Once the problem is solved, a learner can gain wisdom from the approach. The eastern learning approach starts from the motivation of satisfaction of finding truth, and then a learner will judge the new event by his/her past experience via a holistic perspective and consult to internal familiars, and to focus on the process. Once the truth is found, a 
learner can gain wisdom from the approach. The third approach is a mixture of both eastern and western approach to gain wisdom.

\section{Conclusions}

Our hope is to explore how successful accounting managers learn and create managerial wisdom through various approaches and impacts from a multicultural-perspective. Comparing and categorizing findings these conclusions can be reached.

Three learning and wisdom creation patterns can be categorized especially suitable for managers in western, eastern or mixed cultural backgrounds.

\section{Discussion and Contributions}

This research contributes to fill this theoretical and perspective gap by providing a complete multicultural perspective from six cases of accounting manager learning and wisdom creation to fit different cultural needs.

\section{Implications}

The way that managers learn efficiently is to choose the most suitable learning and wisdom creation type based on learners' cultural background (Berman, 1981; Rowley, 2006). Therefore, we proposal a multi-modular program and course design to fit their multi-cultural background and performance evaluations.

\section{Further Research}

Further research can contribute to a wider scope among disciplines. Other studies can also find out what are integrated learning patterns or processes help managers become wise among eastern, western and mixed cultural backgrounds?

\section{Acknowledgment}

This study was funded by the projects coded GDGZ14Z019;15G114;Yue Jian Gui[2015]9;Yue Cai Jian[2014]564;Yue Gao Gui[2015]72; Yue Gao Gui[2015]72-1221.

\section{References}

[1] Baark, E. New Modes of Learning in Services: A Study of Hong Kong's Consulting Engineers, Industry and Innovation. 12(2). 2005. 283-301.

[2] Bennis, W. \& O’Toole, J. O. How Business Schools Lost Their Way? Harvard Business Review, 83(5). 2005. p98-104.

[3] Berman, M. The Reenchantment of the World, Cornell University Press, Ithaca, NY. 1981.

[4] Blasco, M. Cultural Pragmatists? Student Perspectives on Learning Culture at a Business School, Academy of Management Learning \& Education. 8(2). 2009. p174-187

[5] Chia, R. From Knowledge-Creation to the Perfecting of Action: Tao, Basho and Pure Experience as the Ultimate Ground of Knowing, Human Relations. 56(8). 2003. p953-981.

[6] Cooper, D. R. \& Schindler, P. S. Business Research Methods. Publisher: McGraw-Hill College. 2010.

[7] deCharms, R. C. Information Coding in the Cortex by Independent or Coordinated Populations, Proceedings of the National Academy of Sciences of the United States of America. 95(26). 1998. p15166-15168.

[8] Droit, R. P. La Philosophie Expliquee a Ma Fille. Publishing: du Seuil. 2004. 
[9] Helgesen, S. The Practical Wisdom of Ikujiro Nonaka, strategy+business.53. 2008.

[10]Holliday, S.G. \& Chandler, M. J. Wisdom: Explorations in Adult Competence, Karger,Basel. 1986.

[11]Langer, E. J. Mindful Learning, Current Directions in Psychological Science. 9(6). 2000. p220-223.

[12]March, J. G. Exploration and Exploitation in Organizational Learning, Organization Science, 2. 1991. p71-87.

[13]March, J. G. A Scholar's Quest, Journal of Management Inquiry.12(3). 2003.

[14]Nonaka, I. The knowledge creating company. Harvard Business Review. 1991, 69 (6 Nov-Dec): 96-104.

[15]Nonaka, I. \& Takeuchi, H. The Knowledge-Creating Company: How Japanese Companies Create the Dynamics of Innovation. Publisher: Oxford University Press, USA. 1995.

[16]Rowley, J. What do We Need to Know about Wisdom?, Management Decision. 44(9). 2006. p1246-1257.

[17]Scarborough, J. 'Comparing Chinese and Western Cultural Roots: Why 'East Is East and....', Business Horizons. November-December. 1998.

[18]Senge, P. M. The Fifth Discipline: The Art and Practice of The Learning Organization. Publisher: Bantam Dell Pub Group. 2006.

[19]Starkey, K., Hatchuel, A., \& Tempest, S. Rethinking the Business School, Journal of Management Studies, 41(8). 2004. p1521-1531.

[20]Tang, J. Y. Essential of Philosophy. Taiwan Student Publishing. 1980.

[21]Weick, K. E. \& Sutcliffe,K. M. Mindfulness and the Quality of Organizational Attention, OrganizationScience. s17(4). 2006. p514-524.

[22]Yang, B., Zheng, W. \& Li, M. Confucian View of Learning and Implications for Developing Human Resources, Advances in Developing Human Resources. 8(3). 2006. p346-354.

[23]Yin, R. K. Case Study Research: Design and Methods, Applied Social Research Methods Series. Sage Publishing. 2008. 